CIRR XXI (73) 2015, 25-56

ISSN 1848-5782

UDC 327:34 173)

DOI 10.1515/cirr-2015-0010

\title{
Obama's Dual Discourse on American Exceptionalism
}

Miloš Hrnjaz, Milan Krstić

\section{Abstract}

This paper analyses the highly contested concept of American exceptionalism, as described in the speeches of Barak Obama. The authors of the paper use discourse analysis to show that Obama is using the idea of American exceptionalism on two levels: US foreign policy and the US stance towards international law. Our conclusion is that Obama uses an implicit dual discourse in both these fields. Obama favours active US foreign policy, based on soft power instruments and multilateralism. He insists that American exceptionalism does not mean that the US can exempt itself from the norms of international law, however, he does not think the US should always have a very active foreign policy. He makes room for unilateral acting and the use of hard power instruments in foreign policy. He allows for the use of force even if is not in accordance with the norms of international law, when US national interests are threatened.

\section{KEY WORDS:}

US foreign policy, Obama, American exceptionalism, international law 


\section{Introduction}

On the 10th of September 2013, Barak Obama gave a speech regarding the situation in Syria. At the end of the speech he said that "America is not the world's policeman... But when... we can stop children from being gassed to death... I believe we should act. That's what makes us exceptional" (Obama 2013a). The following day, the New York Times published Vladimir Putin's text in which he made a comment about American exceptionalism: "[M]y working and personal relationship with President Obama is marked by growing trust. I appreciate this. I carefully studied his address to the nation on Tuesday. And I would rather disagree with a case he made on American Exceptionalism... It is extremely dangerous to encourage people to see themselves as exceptional, whatever the motivation" (Putin 2013). He also said that "the law is still the law, and we must follow it whether we like it or not" (lbid.).

Putin's criticism gained a great deal of attention in the US media, and although Obama did not stop using the term 'American exceptionalism' he was criticised for not believing in it enough (File 2015). The crisis in Ukraine opened the debate over Vladimir Putin's hypocrisy and the genealogy of the Russian exceptionalism. Arguments between Moscow and Washington about the potential influence of the idea of American exceptionalism on American foreign policy and its stance towards international law are still being exchanged today (Security Council of Russian Federation on US National Security Strategy 2015).

These examples illustrate the importance of the use of the idea of American exceptionalism. American exceptionalism represents one of the most important aspects of American identity. The best indicator for this claim is the fact that exceptionalism is widely accepted in public opinion as something that characterises the USA (Jones 2010).' There is no single fixed meaning of American exceptionalism, however, and the description of this concept is variable. On the one hand, different perceptions of the American role in the world, coming from the different variants of American exceptionalism, might lead to completely different practices. On the

1 Although the Pew Research Center poll from 2014 shows that belief in American exceptionalism: "has declined 10 points since 2011" it is still very high (Source: Tyson, A., 2014. Most Americans think the USA is great but few say it's the greatest. Pew Research Center. Available at: http://www.pewresearch.org/fact-tank/2014/07/02/most-americansthink-the-u-s-is-great-but-fewer-say-its-the-greatest/ [accessed May 29 2015]. 
other hand, different practices in American foreign policy might lead to a change in the discursive articulation of the concept in the purpose of adjustment of the identity with the current practice and consequential legitimisation of the practice.

In this paper we analyse the way Barak Obama uses the idea of American exceptionalism on two levels: US foreign policy and the US stance towards international law. Our main conclusion is that Obama uses implicit dual discourse in both these fields. In US foreign policy Obama predominantly uses the term 'American exceptionalism' as consists of an active foreign policy, favours a multilateral to a unilateral approach, and insists on the importance and efficiency of the soft power instruments of foreign policy instead of hard power. There is dualism present in Obama's discourse however, because his perception of activism in foreign policy is not without boundaries, unilateralism is not inconsistent with exceptionalism, and "smart" use and the development of hard power are also acknowledged as important.

Similarly, in the context of the US stance towards international law, Obama regularly states that America should not be exempt from international legal order, and that what makes the US exceptional is not an ability to flout international norms and the rule of law, but the willingness to confirm them through US actions. Obama's discourse in the field of the prohibition of the threat or use of force in international relations, however, reveals that he is trying to "maintain the right" of the US to use force whenever it is in accordance with their own national interest.

This research paper consists of six chapters. After the introduction, we explain in Chapter II the analytical framework of our research. In Chapter III we briefly explain the genealogy of 'American exceptionalism'. In Chapter IV we analyse Obama's discourse on American exceptionalism towards US foreign policy. In the fifth chapter we apply the same analysis to Obama's discourse on American exceptionalism in international law. Finally, in Chapter VI we make concluding remarks. 


\section{A Analytical Framework}

Theorists of international relations (IR) have recently paid more attention to the concept of American exceptionalism, as an important part of US identity. American exceptionalism is probably one of the most important elements of US identity. As Restad (2012: 53) notes, many see American identity and American exceptionalism as equivalent. Most US foreign policy writers treat identity and 'domestic ideas about what kind of country the United States is', as important in the explanation of its foreign policy (ibid). The role of identity in foreign policy is acknowledged in some of the most important theoretical approaches, such as neoclassical realism, liberalism, social constructivism, as well as by critical IR approaches.

Social constructivism places special emphasis on identity. For constructivists, identity is a key issue in the construction of reality, since "the more we act toward an entity as if it has a particular representation or meaning, the more that entity can take on that representation" (Najak and Malone 2015: 256). The poststructuralist approach also places special emphasis on identity. It considers identity and (foreign) policy as mutually constitutive and discursively linked (Hansen 2006: 25). Adjustments to both practice (policy) and identity are possible through discourse. The goal of foreign policy actors "is to present foreign policy that appears legitimate and enforceable to its relevant audience" (Hansen 2006: 26).

For the purpose of this paper, it is sufficient to conclude that the concept of American exceptionalism is generally considered relevant in the analysis of American foreign policy, and especially in the US attitude towards international law. In this paper, we accept this widespread attitude. We additionally underline the thesis of Hughes (2015: 528), explaining that the relevance of this concept for IR scholars is "that it provides a cultural mechanism for legitimating foreign policy decisions and practices". Since there is no single and fixed meaning of this concept, we find it theoretically and practically relevant to explain how Barak Obama, as a key US foreign policy decision-maker, understands and uses this concept. It is a first and necessary step for any further theorisation of the influence of this aspect of US identity in its foreign policy. 
In order to conduct our research, we focus on the way President Obama uses the concept of American exceptionalism in his speeches related to foreign policy and international law issues. We therefore use a method of discourse analysis. The objects of our analysis are Obama's public speeches. We do not specifically analyse Obama's foreign policy practice outside the discourse.

Despite the fact that there is no single and fixed meaning of American exceptionalism, there were some patterns (or "genres") of its use in history. Prescriptions of different patterns for US foreign policy and stance towards international law are especially important for our analysis. In order to clarify Obama's understanding of the concept in foreign policy and international law issues, we will, therefore, adopt a two-level research framework:

1. Secondary source literature review -which will make it possible for us to locate different "genres" in the meaning of American exceptionalism in the context of foreign policy and international law;

2. Analysis of the primary sources (Obama's speeches) - which will enable us to classify Obama's American exceptionalism discourse in these genres of meaning.

\section{The notion of American exceptionalism}

American exceptionalism is an essentially contested concept. Various US statesmen, politicians and intellectuals have associated it with different meanings, and therefore, certain social scientists made efforts to define the most proper and precise meaning of this concept. One group of social scientists conducted an in-depth historical, sociological and political analysis in order to question the old Tocqueville (2004) thesis that America is qualitatively different (or an exception, as it was later framed) to the rest of the world. The American political scientist Lipset (1997) is a typical representative of this group. 
In the field of International Relations, however, the majority of scholars have focused on clarifying and analysing the influence of the phenomenon of American exceptionalism on US foreign policy (Deudny and Meiser 2012; Hodgson 2009; Bachevic 2008; McCrisken 2003; McEvoy-Levy 2001). This means that these scholars were not questioning whether America is exceptional according to particular criteria, but whether Americans believe that America is exceptional, and how this important belief (ideational variable) influences US foreign policy.

A typical representative of realist theory, Steven Walt (2011), understood this concept as something similar to American primacy in power and the tendency to perceive others in the international arena as unequal. Liberal approaches associated American exceptionalism with the unique character of American democracy and with that what Tony Smith (1994) calls 'the American Mission' - the possibility of spreading democracy around the globe, and "make of world a better place".

The poststructuralist approach adopted by Pease (2009: 9) considered American exceptionalism as a national "fantasy", composed of "incompatible elements", which actually made it possible to survive and adapt to different circumstances. He considered the evolution of this concept as a way of "othering" primarily of the Soviet Union, but also of Europe and the so-called 'third world' (Pease 2009: 10-11). Najak and Malone (2012), put additional emphasis on the role of American exceptionalism discourse as an addition to American Orientalism discourse, and treated it as a way US distinguishes itself from "others" in the Western world, especially Europe.

Most relevant for our analysis are authors who undertook comprehensive research into the way in which the concept was used and the meaning it had in public debates about foreign policy. One of the most important contributions regarding the patterns of use of this concept in foreign policy is work of McCrisken (2003). He claims that there were two different strands of American exceptionalism which had two different foreign policy prescriptions: 1) exemplary - prescribing isolationism; and 2) missionaryprescribing an active international role. Deudny and Meiser (2012) confirm that American exceptionalism has been taken as fundamental to both activism and isolationism at different periods. 
More recently, Leah Achor (2012) conducted a detailed analysis of the patterns in which "American exceptionalism" was used over the last few centuries and concluded that there were seven different patterns (genres). Based on the criteria of prescriptions for foreign policy present in American exceptionalism discourse, Achor (2012) defines three different groups: 1) isolationism, protectionism, unilateralism; 2) active foreign policy; and 3) strong multilateralism.

Several works have criticised Achor's thesis, based on the distinction between isolationism and internationalism. Hughes (2015: 541) argues that the work of the majority of IR scholars who accept the distinction between isolationism and internationalism is based on the findings of "lazy historiography". He points out the findings of revisionist historians, such as William Appleman Williams, which have challenged the thesis that the US was ever really isolationist (ibid). Previously, Restad (2012) also criticised research based on the dichotomy explored by McCriksen, and the many other political scientists that have followed his ideas, suggesting that the thesis of American isolationism is outdated.

We respect the findings of these critics, however, we consider that a negation of the existence of pure isolationism in US foreign policy history does not mean that different conceptions of American exceptionalism do not contain different prescriptions regarding the scope and level of activity of US foreign policy. In addition, the period in which America was focused only on the western hemisphere, even if we do not call it "isolationism", was definitely more passive towards the world as a whole than the period that came after. As Mearsheimer (2011: 18) points out, there are still libertarians today advocating US foreign policy similar to isolationism. These libertarians actually believe that the US is different and better than other countries in the world.

We thus expand our model in comparison with McCriksen's conventional dichotomous model and adjust the content of his main dichotomy to the findings of the critics. The model that will be used in this work to analyse foreign policy oriented aspects of American exceptionalism discourse is based on three different dichotomies. 
The first is the dichotomy between: a) active foreign policy, and b) passive foreign policy. For the reasons explained above, we find this a more appropriate dichotomy than isolationism/internationalism. The second dichotomy is the dichotomy between: a) unilateralism, and b) multilateralism. This distinction helps us to clarify whether the prescriptions derived from discourse are tied to the unilateral US role in the international politics, or to a multilateral approach which seeks to find more partners for the US. Finally, as Stretch and Mara (2014: 5) argue in their article, the roots of American exceptionalism could be traced back both to hawkish (Jackson's expansionism) and dovish policies (Wilson's idealism). The main difference between hawks and doves today lies in different perceptions of the usefulness of foreign policy instruments. Our third dichotomy therefore takes into account two basic means of power (Nye 2004: 25) as a basis for different foreign policy instruments: a) hard power, and b) soft power.

We believe that these three dichotomies present, historically, the most important variations in the discursive framing of this concept. In the following chapter, we will try to locate Obama's use of this discourse in one of the three categories (genres) on both scales.

American exceptionalism is not an essentially contested concept only in the field of foreign policy. Its connection or even tension with the norms of international law is well established (Ignatieff 2009; Koh 2003; Posner and Bredford 2011, etc.). Unfortunately, the dichotomies that we suggested in the analysis of the relationship between the concept of American exceptionalism and foreign policy were not very useful in this sense. Neither active nor passive foreign policy explains the relationship between the concept of American exceptionalism and international law. The same is true for unilateralism and multilateralism: unilateral selfdefence, for example, could be in accordance with international law, but multilateral actions, such as that in the Federal Republic of Yugoslavia in 1999 or Iraq in 2003, were violations of international law norms. This is why we need to make a different analysis of the relationship between the concept of American exceptionalism and international law.

The doctrine of international law reveals different interpretations of the influence of the use of the concept of American exceptionalism in international law norms. Koh (2003: 1482), for example, states that "the 
term "American exceptionalism" has been used far too loosely and without meaningful nuance". This is why he suggests four possible meanings of American exceptionalism: distinctive rights, different labels, the "flying buttress" mentality, and double standards (Koh 2003: 1483). At the same time he finds that the most dangerous meaning of American exceptionalism is the last one-double standards. By double standards Koh means a situation in which "the United States proposes that a different rule should apply to itself than applies to the rest of the world" (Koh 2003: 1486).

Another relevant example is Ignatieff's three different interpretations of the concept of American exceptionalism: the first is connected with the USA reservations, non-ratification or non-compliance of human rights and humanitarian law conventions (Ignatieff 2009: 3). The second is encompassed by the term 'double standards' - "judging itself and its friends by more permissive criteria than it does its enemies" (ibid). The third is connected with USA denial of the jurisdiction of human rights law within its own domestic law.

Bredford and Posner strongly criticise the aforementioned and similar classifications of the concept of American exceptionalism. They offer a different explanation for United States foreign policy and its stance towards international law by claiming that there is nothing exceptional in American exceptionalism and that every powerful country is exceptional in its own way. It is obvious that the term exceptional is differently understood in the work of Bredford and Posner. They claim that all powerful nations "advance interpretations of international law that reflect their values and advance their interests" (Ignatieff 2009: 5). Bredford and Posner see a strong difference between this version of exceptionalism and the concept of exemptionalism which suggests "that the rules of international law... apply to all states except for one particular state" (Ignatieff 2009: 7). To conclude, they believe that there is an American exceptionalism which is not so very different from that of the Chinese one or that of the European Union, but that there is no such thing as American Exemptionalism.

For the purpose of this analysis, we are not going to use this distinction between the terms exceptionalism and exemptionalism. The main reason for this is that we are going to analyse Obama's discourse about the American stance towards international law. Obama does not use the 
term exemptionalism, although he sometimes criticises a practice that could be very similar to this concept. We are thus going to treat the term exemptionalism as part of the term exceptionalism.

Ultimately, we would like to emphasise that the sovereign equality of states as a general principle of international law does not mean an absolute legal equality of all states in international community (Simpson 2004). In other words, in some specific areas of international law, some states could be an exception, such as when great powers, including the United States, have a special legal status in certain situations (the most obvious example is the status of permanent membership in Security Council). It is, however, important to bear in mind that this special legal status is accepted by other subjects in the international community. Otherwise, we are dealing with the unilateral promotion of so-called exceptionalism, which is used only to legitimize violations of the international law norms.

\section{Obama's discourse on American exceptionalism and US foreign policy}

Foreign policy connotations and prescriptions are an integral part of the American exceptionalism discourse. President Obama often used this concept in his speeches, even more so than George W. Bush (Gilmore 2013: 77-78). Despite this, President Obama was widely criticised for his "lack of belief" in American exceptionalism by conservative politicians such as Mitt Romney (Rucker 2012) and Rudi Giuliani (File 2015). This concept is very important for Barack Obama, and it was the topic of his first political speech at national level (Obama 2012a). Its content for Obama was not the same as that understood by Bush, Romney or Giuliani. The claims of his critics are actually based on this different understanding and definition of the concept, in comparison with those of Obama's predecessor and the current conservative political elite.

Barack Obama belongs to the group of believers and proponents of American exceptionalism that prescribes active foreign policy, favours 
multilateral to unilateral approach and insists on the importance and efficiency the soft power instruments of foreign policy as something that makes America exceptional. Obama's perception of activism in foreign policy is not without any boundaries, however: unilateralism is not inconsistent with exceptionalism, while "smart" use and the development of hard power are also acknowledged as important. Therefore, while emphasising one particular combination of these factors (activemultilateral-soft), Obama more or less directly legitimises their contrasts as well, as something that is at least not contradictory to American exceptionalism, if not an integral part of it. We claim that Obama uses an implicit dual discourse regarding American exceptionalism, which is unbalanced in favour of the combination of factors. In this chapter we will further develop and try to explain our thesis about Obama's unbalanced dual discourse, analysing in detail Obama's American exceptionalism discourse position in the three dichotomies described above.

\section{a. Active vs. passive foreign policy}

President Obama is a strong and decisive proponent of active American foreign policy, and considers US activity and decisiveness to confront the threats on international level to be the essence of American exceptionalism (Obama 2015a). This was often associated in Obama's speeches with historical examples of what Obama considered the brightest side of American activism and international leadership. In his famous interview during the G20 summit in 2009, he underlined the role of the USA in European liberation, reconstruction and unification, pointing out the expenditure of American resources, sacrifices of the troops and leadership of the new alliances after the Second World War as something exceptional in history (Obama 2009a).

In another speech, Obama analysed various historical challenges for American leadership in the twentieth century history of the USA (the Great Depression, Perl Harbour, Vietnam, the economic rise of Japan and the Asian tigers) concluding that the US always managed to overcome these potential problems and to remain a leader (Obama 2012b). As Obama points out, the USA is therefore an "indispensable nation in world affairs" and "one of the many examples of why America is exceptional" (ibid). This attitude implicitly contains a message that a passive policy which would lead toward an abandoning of American leadership would not be 
considered as part of genuine American exceptionalism in the historical continuum.

Regarding contemporary issues, Obama stated that US engagement and decisiveness to "stop children being gassed to death", such as in Syria, is something that makes the US exceptional (Obama 2013a). Obama even explicitly emphasised the risk to the whole world of American passivity and isolationism in the case of disengagement from regions such as the Middle East:

\begin{abstract}
"Now, I believe such disengagement would be a mistake. I believe America must remain engaged for our own security. But I also believe the world is better for it. Some may disagree, but I believe America is exceptional, in part because we have shown a willingness through the sacrifice of blood and treasure to stand up not only for our own narrow self-interests, but for the interests of all" (Obama 2013b).
\end{abstract}

It is important to note that Obama's perception of activism and leadership is not entirely without boundaries. He warned against "reacting to the headlines instead of using our heads" (Obama 2015b) and explicitly stated that "America is not a world policeman" (Obama 2013a). In practice, however, it is often hard to distinguish positive active foreign policy from negative "world policeman" foreign policy. Boundaries between these two concepts are usually found in international law, as well as the legitimate interests of other states. It is thus very important to analyse the way Obama perceives these concepts in the context of American exceptionalism. As it can be argued, Obama's perception of the importance of International Law and multilateralism for American exceptionalism is somewhat ambiguous and without clear shape. Consequently, it is hard to define where precisely the border should be for American activism, if the US wants to stay positively exceptional, instead of becoming a negative interference in international affairs.

b. Unilateralism vs. multilateralism

American exceptionalism has often been associated in Obama's speeches with multilateralism in foreign policy. This association shows us 
that Obama's perception of active foreign policy does not include the aforementioned "world policeman" model, based on unilateralism. His attitude is that American exceptionalism and global leadership must, in the most important global processes, involve other relevant international actors as well. This approach was called "leading from behind" (Halper 2012). Obama noted US coalition-building skills as one of the things that makes the US exceptional:

"Looking to the future instead of the past, making sure we match our power with diplomacy and use force wisely, building coalitions to meet new challenges and opportunities, leading always with the example of our values_-that's what makes us exceptional. That's what keeps us strong. That's why we have to keep striving to hold ourselves to the highest of standards: our own" (Obama 2015b).

In the interview noted above on American exceptionalism during a G20 summit, Obama stated that America's "extraordinary role in leading the world" is not in contradiction to creating partnerships, since the US "can't solve these problems alone" (Obama 2009a). Obama thinks that US values orienting the country's strategic thinking towards multilateralism. He pointed out that the American tendency to "think what's good for the world", and not only to think about its own interest, is one of the things that make America exceptional (Obama 2011 a).

This does not mean that unilateralism is completely erased form Obama's American exceptionalism discourse. On the one hand, in his statement on the 2015 National Security Strategy which glorifies the "exceptional role" of the US, President Obama stated that there is a possibility of unilateral reaction when "core interests" are endangered, although he added that even then it is better to tackle issues multilaterally (Obama 2015c). In his 2014 West Point address, Obama announced the possibility of the unilateral use of military force, if "core interests demand it" (Obama 2014a). On the other hand, in the same address (which contains many explicit references to American exceptionalism), President Obama stated that an important element of American leadership was international institutions since "they reduce the need for unilateral American action" (ibid). 
It is obvious that multilateralism is something Obama considers essential for American leadership and exceptionalism, but unilateralism is perceived as something that is not necessarily in contradiction with these concepts, if it is used only when "core interests" are in question. This concept of "core interests" is somewhat ambiguous, however, and open to different interpretations. It is therefore necessary to conclude that, while favouring and emphasising multilateralism as an essential part of American exceptionalism, Obama also legitimises the possibility of unilateral action which would not hinder this exceptionalism.

\section{c. hard power vs. soft power}

"The question is not whether America leads in the world, but how", said President Obama in January 2015 (Obama 2015b). The issue of the nature and form of American power is obviously very important to the president. If we had to describe Obama's approach to the most desirable form of power in two words, the most precise concept would be smart power. This term was coined by Joseph Nye (2009) to describe the successful combination of hard and soft power instruments. In his speeches President Obama underlined explicitly and implicitly the need to rely on instruments of both hard and soft power. He claimed that the skill of matching "power with diplomacy" and the wise use of force is something that makes the US exceptional (Obama 2015b).

Obama put much more emphasis in his speeches on the effectiveness of soft power than on hard power instruments as the core content of American exceptionalism. Earlier diplomatic successes, such as McCain's effort to restore diplomatic ties with Vietnam, were characterised as exceptional (Obama 2012c), and the restoration of diplomatic ties with Cuba and success of the diplomatic negotiations with Iran were also glorified (Obama 2015b). Obama also claimed that American leadership in science and research (Obama 2014b), as well as the attractiveness of American universities (Obama 2014c) is something that makes the US exceptional. He even underlined the importance of the entertainment industry in American superpower status and exceptionalism (Obama 2013c). American ideals and its internal inclusiveness are, according to Obama's speeches, the essence of the American power to attract people from around the world and of its exceptionalism (Obama 2014d, 2014e, 2012d). In one of his speeches, Obama emphasised: 
"...I travel around the world a lot, and I'm not somebody who expects that other people love their country any less than we love ours, but I will tell you there is something exceptional and special about this country. And there are very few people around the world who wouldn't do everything they could to be citizens of the United States or have the same opportunities that we have" (Obama 2012e).

In his speeches involving American exceptionalism, Obama also stated his opinion of the lack of hard power in tackling some of the most problematic global issues. The President said that military power is not enough to solve issues such as world terrorism, but that other means are necessary to fight its causes (Obama 2015c). Ending the wars in Afghanistan and Iraq was also treated as something good for America (Obama 2012b). Already noted examples of Obama's rhetorical tendency to avoid war solutions can be summarized in his following words - "the American people expect us only to go to war as a last resort" (Obama 2015b).

Obama definitely favours soft to hard power and emphasises it as more important for the content of American exceptionalism. It does not, however, mean that President Obama leaves no room for hard power. On the contrary, although it does not seem so at first sight, he actually leaves a great deal of room for the use of such power as an instrument of foreign policy and also connects it with American exceptionalism. The "sacrifice of blood and treasure" for global interest is believed by Obama to be part of those things that make America exceptional (Obama 2013b). He also classified the patriotism of US military servants in this category of exceptionality (Obama 2014f). It is important to note that while often placing emphasis on ideas and creed as the essence of American exceptionalism, Obama does not negate the importance of the military and economy as aspects of hard power for American exceptionalism, but usually suggests that they are not enough (Obama 2013b). This does not mean that they are not also important. Obama's message is that they are not enough for exceptionalism on their own, but that they are important, and probably necessary for it.

It is also important to note that Obama avoided using the term "war" in the context of American exceptionalism, but he did not resort to connecting 
various other instruments based on hard power with this concept. First of all, he congratulated economic coercive instruments, such as economic sanctions, for the pain they impose on the Russian economy (Obama 2015c). Secondly, Obama openly applauded the use of hard (military) power in a non-coercive way for fighting global problems, such as Ebola, and marked these achievements of American military as exceptional (Obama 2015a). Finally, as we have already noted, he left space for the direct use of coercive military measures when "core interests and values" are threatened, in a "smart" manner.

It is obvious that, despite the constant highlighting of soft power instruments and insisting on the "smart" and bounded use of hard power, Obama's exceptionalism discourse leaves a great deal of space for the legitimate unbounded use of force. Phrases such as "core interests", "national interests", "global interests" or "national security" are essentially contested and there is no consensus regarding the precise content of these categories, which should if necessary be protected even by force. The meaning of these concepts is shaped by various public actors in the security sector, and the US President is probably the figure with the greatest degree of social capital possession. The President therefore leaves enough space to frame a single issue as a "national security threat" (securitize) in the future, and consequently legitimise the use of force as a necessary special measure for dealing with that threat. ${ }^{2}$

\section{Obama's speeches on American exceptionalism and international law}

In his very first interview after inauguration in 2009, Barak Obama noted "... that the language we use matters" (Obama 2009b). Although the notion of international law is not so frequently noted in his speeches, there are some important exceptions. We believe this is why it is more illustrative to focus specifically on one of these exceptions in order to show how Obama understands notions of international law, and American exceptionalism,

2 More details about securitization theory in security studies: Buzan, B., Waver, O., De Wilde, J., 1998. Security: A New 
and their relationship. We are going to focus on the speech Obama gave at West Point on the $28^{\text {th }}$ of May 2014.

In this part of our paper we claim that Obama uses implicit dual discourse about the relationship between the concept of American exceptionalism and international law. Although on a general level Obama declares that the US should not be exempt from international law norms, he "reserves the right" of the US to use force in international relations in a way which could be hostile to international law norms.

It is interesting to note that in his West Point speech Obama mentioned international law or norms of international law six times (as far as we know, more than in any other of his speeches during his two mandates). This is intriguing considering the place he made the speech (a military academy).

We would like to underline and subsequently analyse two aspects of Obama's speech at West Point:

1. The part of the speech in which we can identify his understanding of the right of the US to use force in international relations;

2. The part of his speech in which he talks about the general importance of international law and the US stance toward it.

It may be fair to note at the beginning that the principle of the prohibition of threat and use of force in international relations is probably the greatest challenge of all in the context of compliance with norms of international law. This is particularly the case taking into account the position of the US as the only military super-power in the world. We believe that this is the reason special attention should be paid to US self-perception in this field of international relations and international law.

At the beginning of his speech Obama stated that America is an indispensable nation which must always lead on the word stage (Obama 2014a). At least two interpretations of this statement are possible:

1. America should defend this status by using all necessary means 
(including its military power) against any state who dares to (even peacefully) challenge this status;

2. The status of a leader on the world stage should be preserved by peaceful and legal instruments.

It seems obvious that the first interpretation is contrary to the international legal order and that the second is complementary: states have a right to compete and enlarge their power, but they have to do that in accordance with the rules of international law.

\section{Obama also noted that:}

"[t]he United States will use military force, unilaterally if necessary, when our core interests demand it - when our people are threatened; when our livelihood is at stake; or when the security of our allies is in danger... America should never ask permission to protect our people, our homeland, or our way of life".

This is not the terminology of international law and Obama is not obliged to use it in this kind of speech. It is, however, interesting to see how it fits into the international legal framework. There is a consensus (Bredford and Posner would say it was the core of international law) in the international legal doctrine that the use of force is prohibited by Article 2 (4) of the UN Charter $^{3}$ and customary international law, although there are (at least) two exceptions to this prohibition: the authorisation of the use of force by the UN Security Council by Article 42 of the UN Charter ${ }^{4}$ and self-defence in accordance with Article $51^{5}$ of the same legal instrument (Gray 2008; Dinstein 2011, Corten 201 1). Nevertheless, there are fierce debates not only about the interpretation of these articles, but also about other possible

3 Article 2 (4) of the UN Charter: "All Members shall refrain in their international relations from the threat or use of force against the territorial integrity or political independence of any state, or in any other manner inconsistent with the Purposes of the United Nations".

4 Article 42 of the UN Charter: "Should the Security Council consider that measures provided for in Article 41 would be inadequate or have proved to be inadequate, it may take such action by air, sea, or land forces as may be necessary to maintain or restore international peace and security. Such action may include demonstrations, blockade, and other operations by air, sea, or land forces of Members of the United Nations".

5 Article 51 of the UN Charter: "Nothing in the present Charter shall impair the inherent right of individual or collective self-defence if an armed attack occurs against a Member of the United Nations, until the Security Council has taken measures necessary to maintain international peace and security. Measures taken by Members in the exercise of this right of self-defence shall be immediately reported to the Security Council and shall not in any way affect the authority and responsibility of the Security Council under the present Charter to take at any time such action as it deems necessary in order to maintain or restore international peace and security". 
exceptions. The International Court of Justice adopted a restricted understanding of the scope of these exceptions in its jurisprudence (Military and Paramilitary Activities in and Against Nicaragua, Merits, Judgment. I.C.J. Reports 1986, p. 14), but there was serious opposition, especially in American legal doctrine, to this viewpoint.

It is also good to note that in the same speech Obama claimed that the US could use military force unilaterally, if necessary. International law does not prohibit the unilateral use of force in a situation of self-defence, however, even then, self-defence could be used only until the UN Security Council (UNSC) take measures necessary to maintain international peace and security (art. 51 of the UN Charter). Additionally, self-defence must be proportional and necessary (Obama also noted that the use of force needed to be proportional, effective and just). That was also confirmed in jurisprudence of the International Court of Justice (Oil Platforms (Islamic Republic of Iran v. United States of America), Judgment, I.C.J. Reports 2003, p. 161). Ultimately, even if the UN SC authorizes a state to use force, as in the case of its Resolutions 1368, 1373, 1377 and 1378, the use of force must be in accordance with the mandate defined by these Resolutions. ${ }^{6}$

Be that as it may, Obama also suggested that in taking direct action we must uphold standards that reflect our values, but immediately explained what he meant by our values: taking strikes only when we face a continuing, imminent threat, and only where... there is near certainty of no civilian casualties. This raises the difficult issue of the scope of the self-defence rule in the context of the concept of so-called preventive self-defence. There is a fierce doctrinal debate about the existence of this concept in international law. There are authors such as Corten, who claim that the concept of preventive self-defence is illegal because it is not in accordance with Article 51 of the UN Charter and the customary law in this field (Corten 2010: 406). It seems that most states in the international community share this view (Corten 2010: 425), however, there are also a variety of views suggesting that preventive and/or pre-emptive selfdefence is allowed in international law (Higgins 1963; Wedgwood 2000). Until now, the ICJ has noted the concept of preventive self-defence in several cases (e.g. Armed Activities on the Territory of the Congo

6 It is interesting to note that Obama promised in his speech at West Point that at the end of this year (2014), a new Afghan President will be in office and America's combat mission will be over. 
(Democratic Republic of the Congo v. Uganda), Judgment, I.C.J. Reports 2005, par. 143) but has never made a judgment that was based on it.

Before 11 th September 2001, the US took a cautious stance towards the concept of preventive self-defence in international law (Corten 2010). Even after this date, Marry O'Connell (2002: 50) noted that the US did not recognise the existence of a general rule of international law that would establish the right to pre-emptive self-defence. Accordingly, claiming the right of pre-emptive self-defence on the part of the United States would suggest exemptionalism in the US standpoint toward this international law rule.

Obama probably mentioned the question of civilian casualties in the context of the general principles of International Humanitarian Law (distinction and proportionality). The American use of drones in several countries also raised the question of the legal concept of armed conflict (drones were not only used in countries in which there was an armed conflict in the legal sense, but also in countries such as Yemen where the use of drones was part of the CIA agenda) and targeted killings (Melzer 2008). ${ }^{7}$

As already noted, in his West Point speech Obama also talked about the "right" of the USA to use force without asking permission when its core interests were jeopardised. It is not however clear what Obama perceives as the core interests of the USA - what does he means when he is talking about situations in which people are threatened or where the American way of life needs protection. After all, the International Court of Justice found that self-defence was legal only in the case of an armed attack against the state (Nicaragua). By unilateral use of force to protect our people Obama probably means that the USA will unilaterally use force to protect its nationals outside US borders. The legality of this use of force is controversial in the doctrine of international law, although there have been several situations in which the USA claimed that these kinds of operations were legal (Arend \& Beck 1993).

7 It is interesting to note that the already mentioned Harold Koh, former Legal Adviser of the Department of State (20092013) is the subject of a controversial petition that circulated at NYU where he teaches International Human Rights Law. People who signed the petition (more than 200 hundred students, organisations and "concerned members of NYU and the global community" - https://docs.google.com/forms/d/14tNTa9_WqCgJv3DFu_XVK2zQsfHKwIne5PEu9Ld$2 \mathrm{M} /$ viewform) declared that by publicly defending the policy of the US drone programme and the policy of targeted killing Koh had behaved in a "unacceptable" way and so should not teach a subject such as International Human Rights Law. 
Even more controversial is to claim that the states have a right to unilaterally use force without permission in order to protect their own way of life. It is very hard to determine the specific meaning of this claim (even in the US there is strong disagreement regarding the interpretation of their famous expression life, freedom, and the pursuit of happiness) and it is probably even harder to defend the position that every state in the world has a unilateral right to use force in order to defend its own way of life.

To conclude this part of our analysis, it is hard to believe that the US would agree that all nations in the world can use military force, unilaterally if necessary, when their core interests demand it - when their people are threatened; when their livelihood is at stake. It is equally hard to imagine that the US would permit all nations in the world to use force without permission in order to protect their people, their homeland, or their way of life. The US could not be an exception to the complete system of international law regarding the use of force in international relations. That would be an example of the negative exceptionalism noted by Koh, or exemptionalism in the words of Bredford and Posner. Of course, Obama's statement is a political one and could be interpreted differently in order to fit the international legal framework (for example the interpretation that 'protection of the American people' only means self-defence in the case of armed attack against the USA), but our intention was only to stress an interpretation of American exceptionalism that is almost certainly hostile to the order of international law.

We have already noted that in this speech at West Point Obama also made some general remarks about the US stance towards international law. One should bear in mind that almost every political leader in the world would always claim that their country is obeying the norms of international law, however, it is important to see how Obama understands the relationship between American foreign policy and international law.

Obama declares that those who claim respecting international law is a sign of the weakness are wrong. More importantly, he criticised the USA's attitude towards important international legal instruments and offered a (new?) landscape of American leadership that would not be based on the notion of exceptionalism and that would not be hostile to the international legal framework: 
"American influence is always stronger when we lead by example. We can't exempt ourselves from the rules that apply to everybody else. We can't call on others to make commitments to combat climate change if a whole lot of our political leaders deny that it's taking place. We can't try to resolve problems in the South China Sea when we have refused to make sure that the Law of the Sea Convention is ratified by our United States Senate, despite the fact that our top military leaders say the treaty advances our national security. That's not leadership; that's retreat. That's not strength; that's weakness. I believe in American exceptionalism with every fiber of my being. But what makes us exceptional is not our ability to flout international norms and the rule of law; it is our willingness to affirm them through our actions".

Although Obama declared that he believed in American exceptionalism with every fibre of his being, his interpretation of that exceptionalism in this part of his speech is not hostile to the international legal framework (at least declaratory) because he also stated that the USA can't exempt themselves from the rules that apply to everybody else, and that USA is exceptional in its willingness to affirm international norms through its actions. Obama noted two areas of international law and politics in which the USA was severely criticised for double standards: environmental law and the law of the sea (although there are other examples, such as the American position towards the International Criminal Court). Obama's comment on double standards may be understood as his critique of the Senate's practice in the field of ratification of important international agreements. In our opinion this was a message to the US public and senators rather than to people outside the US.

It therefore seems that Obama's discourse about American exceptionalism and international law rests on two basic, but probably opposite foundations. The first is that, at least generally speaking, the US can't exempt itself from the rules of international law that apply to everybody else. The discourse on the rules of the prohibition on the use of force in international relations reveals that, at least in the most sensitive fields of international relations, the US wants to have almost full freedom to protect their own national interests. The question remains whether it is possible to make peace between these two foundations in order to 
create a coherent foreign policy which would be in accordance with norms of international law.

\section{Conclusion}

Due to its popularity and importance for the American public, American exceptionalism has been widely used in recent decades by presidents to justify their actions on the international stage, however, American exceptionalism remains an essentially contested concept. The articulation of its content is one of the most important aspects of the identity of the USA in the international arena. The findings of our analysis of secondary sources showed that in US public discourse there are important differences (even contradictions) in the articulation of this concept in terms of US foreign policy and its relationship with international law. The fact that a particular president uses or does not use the American exceptionalism concept in their public speeches cannot tell us about their foreign policy or stance towards international law. It is necessary to analyse the way a particular president uses this concept and the meanings they associate with it.

Based on the analysis of primary sources (public speeches) we have concluded that Barack Obama has unbalanced the dual American exceptionalism discourse concerning foreign policy and relations with international law. Obama favours active US foreign policy, based on soft power instruments and multilateralism, as something that makes America exceptional. He also insists that American exceptionalism does not mean that the US can exempt itself from the norms of international law, however, Obama's speeches also contain a second aspect in his articulation of American exceptionalism. Obama does not think that the US should always have a very active foreign policy and, more importantly, he makes room for unilateral action and the use of hard power instruments in foreign policy. Regarding international law, he allows for the use of force even if is not in accordance with the norms of international law, whenever US national interests are threatened. The parallel existence of these two approaches is the reason we describe Obama's American exceptionalism discourse as "dual". Clearer articulation and much more 
insistence on the first combination is the reason we added the attribute "unbalanced".

The focus of our research was Obama's discursive articulation of American exceptionalism concerning US foreign policy and its stance towards international law. In other words, we have focused on identity, and not on practice. As we have explained, however, American exceptionalism is considered one of the most important mechanisms for the justification of foreign policy. It is obvious that the dual articulation of this concept allows Obama to justify a wide range of foreign policy practices and practical stances towards international law. The findings of this article should help further research about the way Obama's articulation of this concept influences his foreign policy practice and stance towards international law. 


\section{Bibliography}

Achor, L., 2012. American exceptionalism and its Impact on Presidents' Foreign Policy. The Honors Programs at Geneva College Project. Geneva: Geneva College.

Arend, A. C., Beck, R. J., 1993. International Law and the Use of Force: Beyond UN Paradigm. New York: Routledge.

Bachevich, A. J., 2008. The Limits of Power: The End of American Exceptionalism. New York: Metropolitan Books and Henry Holt.

Bredford, A., Posner, E. A., 2011 . Universal Exceptionalism in International Law. Harvard International Law Journal, 52(1): 1-54.

Byers, T. B., 1997. A City Upon a Hill: American Literature and the Ideology of Exceptionalism. American Studies in Scandinavia, 29: 85-105.

Corten, O., 2012. Law Against War: The Prohibition of the Use of Force in Contemporary International Law. Oxford: Hart Publishing.

Deudney, D. and Meiser, J., 2012. American Exceptionalism. In: Cox, M. and Stokes, D., eds. US Foreign Policy. 2nd ed, 21-40. Oxford: Oxford University Press.

Dinstein, Y., 201 1. War, Aggression and Self-Defence. New York: Cambridge University Press.

Doty, R. L., 2011. Foreign Policy as Social Construction: A Post-positivist Analysis of U.S. Counterinsurgency Policy in the Philippines. In: Carlsnaes W. and Guzzini, S., eds. Foreign Policy Analysis (Volume III). London: SAGE.

File, K., 2015. Giuliani defends Obama criticism, says President doesn't believe in American exceptionalism, television broadcast, Fox News, 20 February. Available at: http://www.foxnews.com/ politics/2015/02/20/giuliani-defends-obama-criticism-sayspresident-doesnt-believe-in-american/ [accessed 10 April 2015].

Gilmore, J. A., 2013. The World's Exceptional Neighbour: Comparative Perspectives on American Exceptionalism in Presidential Discourse 
and the Effects at Home and Abroad. Doctoral thesis. Seattle: University of Washington.

Godgson, G., 2009. The Myth of American Exceptionalism. New Haven: Yale University Press.

Gray, C., 2008. International Law and the Use of Force. New York: Oxford University Press.

Halper, D., 2012. Biden Acknowledges Obama 'Leading from Behind'. The Weekly Standard, 13 October. Available at: http://www. weeklystandard.com/blogs/biden-campaigns-leading-behindforeign-policy_654457.html [accessed 10 April 2015].

Hansen, L., 2006. Security as Practice: Discourse Analysis and the Bosnian War. London, New York: Routledge.

Higgins, R. 1963. The Development of International Law Through the Political Organs of the United Nations. London: Oxford University Press.

Hughes, D., 2015. Unmaking an Exception: A Critical Genealogy of US Exceptionalism. Review of International Studies, First View: 527-551.

Ignatieff, M., ed., 2009. American Exceptionalism and Human Rights. Princeton: Princeton University Press.

International Court of Justice, 2005. Armed Activities on the Territory of the Congo (Democratic Republic of the Congo v. Uganda), Judgment, I.C.J. Reports, par. 143.

International Court of Justice, 1986. Military and Paramilitary Activities In and Against Nicaragua, Merits, Judgment, I.C.J. Reports, 14.

International Court of Justice, 2003. Oil Platforms (Islamic Republic of Iran v. United States of America), Judgment, I. C. J. Reports, 161.

Jones, J. M., 2010. Americans See U.S. as Exceptional; 37\% Doubt Obama Does. Gallup, 22 December. Available at: http://www.gallup. com/poll/145358/americans-exceptional-doubt-obama.aspx [accessed 10 April 2015].

Koh, H. H., 2003. On American Exceptionalism. Stanford Law Review, 55(5): 1479-1527. 
Lipset, S. M., 1997. American Exceptionalism: A Double-Edged Sword. New York: W.W. Norton.

McCrisken, T. B., 2003. American Exceptionalism and the Legacy of Vietnam: US Foreign Policy since 1974. Houndmills: Palgrave.

McDougall, W. A., 2013. The Unlikely History of American Exceptionalism. American Interest 8(4): 7-15.

McEvoy-Levy, 2001. American Exceptionalism and US Foreign Policy: Public Diplomacy at the End of the Cold War. Houndmills: Palgrave.

Mearsheimer, J. J., 2011. Imperial by Design. The National Interest, 111: 16-34.

Melzer, N., 2009. Targeted Killing in International Law. New York: Oxford University Press.

Nayak, M. V. and Malone, C., 2009. American Orientalism and American Exceptionalism: A Critical Rethinking of US Hegemony. International Studies Review 11 (2): 253-276.

Nye, Jr. J. S., 2009. Get Smart: Combining Hard and Soft Power. Foreign Affairs, July-August. Available at: http://www.foreignaffairs.com/ articles/65163/joseph-s-nye-jr/get-smart [accessed 10 April 2015].

Nye, Jr. J. S., 2004. Soft Power: The Means to Success in World Politics. New York: Public Affairs.

O'Connel, M. E., 2002. American Exceptionalism and the Law of SelfDefense. Scholarly Works, Paper 276.

Obama, B., 2009a. The President's News Conference in Strasbourg, transcript, The American Presidency Project, 4 April. Available at: http://www.presidency.ucsb.edu/ws/index.php?pid=85959\&st=ex ceptional\&st $1=$ [accessed 10 April 2015].

Obama, B., 2009b. Obama Tells Al Arabiya Peace Talks Should Resume, transcript, Al Arabyia, 27 January. Available at: http://www. alarabiya.net/articles/2009/01/27/65087.html [accessed 10 April 2015].

Obama, B., 2011. Remarks at an Obama Victory Fund 2012 Fundraiser in New York City, transcript, The American Presidency Project, 30 
November. Available at: http://www.presidency.ucsb.edu/ws/ index.php? pid=108031\&st=exceptional\&st $1=$ [accessed 10 April 2015].

Obama, B., 2012a. The President's News Conference With President Felipe de Jesus Calderon Hinojosa of Mexico and Prime Minister Stephen Harper of Canada, transcript, The American Presidency Project, 2 April. Available at: http://www.presidency.ucsb.edu/ws/index.php ?pid=100451 \&st=exceptional\&st $1=$ [accessed 10 April 2015] .

Obama, B., 2012b. Commencement Address at the United States Air Force Academy in Colorado Springs, Colorado, transcript, The American Presidency Project, 23 May. Available at: http://www. presidency.ucsb.edu/ws/index.php? pid=100920\&st=exceptional\& st $1=$ [accessed 10 April 2015].

Obama, B., 2012c. Remarks on the Nomination of Senator John F. Kerry To Be Secretary of State, transcript, The American Presidency Project, 21 December. Available at: http://www.presidency.ucsb.edu/ws/ index.php?pid $=102784 \&$ st $=$ exceptional\&st $]=$ [accessed 10 April 2015].

Obama, B., 2012d. Remarks at a Victory Celebration in Chicago, Illinois, transcript, The American Presidency Project, 7 November. Available at: http://www.presidency.ucsb.edu/ws/index.php? pid=102576\&st =exceptional\&stl [accessed 10 April 2015].

Obama, B., 2013a. Address to the Nation on the Situation in Syria, transcript, The American Presidency Project, 10 September. Available at: http://www.presidency.ucsb.edu/ws/index.php? pid=104085\&st=e xceptional\&st $1=$ [accessed 10 April 2015] .

Obama, B., 2013b. Remarks to the United Nations Generally Assembly in New York City, transcript, The American Presidency Project, 24 September. Available at: http://www.presidency.ucsb.edu/ws/ index.php? pid $=104276 \&$ st $=$ exceptional\&st $]=$ [accessed 10 April 2015].

Obama, B., 2013c. Remarks at the Headquarters of DreamWorks Animation SKG, Inc., in Glendale, California, transcript, The American Presidency Project, 26 November. Available at: http:// 
www.presidency.ucsb.edu/ws/index.php? pid=104468\&st=excepti onal\&st $=$ [accessed 10 April 2015].

Obama, B., 2014a. Commencement Address at the United States Military Academy in West Point, New York, transcript, The American Presidency Project, 28 May. Available at: http://www.presidency. ucsb.edu/ws/index.php? pid=105220\&st=exceptional\&st $1=$ [accessed 10 April 2015].

Obama, B., 2014b. Remarks at the National Institutes of Health in Bethesda, Maryland, transcript, The American Presidency Project, 2 December. Available at: http://www.presidency.ucsb.edu/ws/ index.php?pid $=107997 \&$ st $=$ exceptional\&st] $=$ [accessed 10 April 2015].

Obama, B., 2014c. Remarks at the White House College Opportunity Summit, transcript, The American Presidency Project, 4 December. Available at: http://www.presidency.ucsb.edu/ws/index.php?pid= 108001 \&st=exceptional\&st $1=$ [accessed 10 April 2015] .

Obama, B., 2014d. Remarks at Del Sol High School in Las Vegas, Nevada, transcript, The American Presidency Project, 21 November. Available at: http://www.presidency.ucsb.edu/ws/index.php?pid= 107932\&st=exceptional\&st $1=$ [accessed 10 April 2015] .

Obama, B., 2014e. Remarks at Buck Lodge Middle School in Adelphi, Maryland, transcript, The American Presidency Project, 4 February. Available at: http://www.presidency.ucsb.edu/ws/index.php?pid= 104676\&st=exceptional\&st $1=$ [accessed 10 April 2015] .

Obama, B., 2014f. Remarks to United States Troops and Department of Defense Personnel at Joint Base McGuire-Dix-Lakehurst, New Jersey, transcript, The American Presidency Project, 15 December. Available at: http://www.presidency.ucsb.edu/ws/index.php?pid= 108033\&st=exceptional\&st $1=$ [accessed 10 April 2015] .

Obama, B., 2015a. Remarks on the United States Response to the Ebola Epidemic in West Africa, transcript, The American Presidency Project, 11 February. Available at: http://www.presidency.ucsb. edu/ws/index.php?pid=109404\&st=exceptional\&st] = [accessed 10 April 2015]. 
Obama, B., 2015b. Address before a Joint Session of the Congress on the State of the Union, transcript, The American Presidency Project, 20 January. Available at: http://www.presidency.ucsb.edu/ws/index. php?pid=108031 \&st=exceptional\&st $1=$ [accessed 10 April 2015].

Obama, B., 2015c. Statement on the 2015 National Security Strategy, transcript, The American Presidency Project, 6 February. Available at: http://www.presidency.ucsb.edu/ws/index.php? pid=109365\&st =exceptional\&st] = [accessed 10 April 2015].

Pease, D. E., 2009. The New American Exceptionalism. Minneapolis: University of Minnesota Press.

Petersen, N., 2012. Lawmaking by the International Court of Justice Factors of Success. In: Bogdandy, von A. and Venzke, I., eds. International Judicial Lawmaking, 41 1-437. Heidelberg: Springer.

Postema, G., 2012. Custom, Normative Practice, and the Law. Duke Law Journal, 62: 707-738.

Putin, V. V., 2013. A Plea for Caution from Russia, New York Times, 11 September. Available at: http://www.nytimes.com/2013/09/12/ opinion/putin-plea-for-caution-from-russia-on-syria.htmle_r=0 [accessed 10 April 2015].

Restad, H. E., 2012. Old Paradigms in History Die Hard in Political Science: US Foreign Policy and American Exceptionalism. American Political Thought 1 (1): 53-76.

Rucker, P., 2012. Romney questions Obama commitment to "American exceptionalism", The Washington Post, 31 March 2012, Available at: http://www.washingtonpost.com/blogs/postpolitics/post/romney-questions-obama-commitment-to-americanexceptionalism/2012/03/31/glQA7xKUns_blog.html [accessed 10 April 2015].

Security Council of Russian Federation on US National Security Strategy, 2015.

Simpson, G. 2004. Great Powers and Outlaw States. Cambridge: Cambridge University Press.

Smith, T., 2012. America's Mission: The United States and the Worldwide 
Struggle for Democracy. Princeton: Princeton University Press.

Streich, G. W. and Marrar, K., 2014. President Obama and American Exceptionalism: Is the United States an Indispensable Nation in a Multipolar World? In: Sharma, D. and Gielen, U.P., eds. The Global Obama: Crossroads of Leadership in the 21st Century, 31-44. New York: Routledge, Taylor and Francis Group.

Tocqueville, A., 2004. Democracy in America. New York: Library of America.

Walt, S., 2011. The Myth of American Exceptionalism. Foreign Policy, 11 October. Available at: http://foreignpolicy.com/2011/10/11/themyth-of-american-exceptionalism/ [accessed 2 April 2015].

Wedgwood, R., 2000. Unilateral Action in the UN System. European Journal of International Law, 11:349-359.

Miloš Hrnjaz (miloshrnjaz@gmail.com) obtained Bachelors degree at the Faculty of Political Science (Belgrade, Serbia). In 2007 he graduated at the Diplomatic Academy of Ministry of Foreign Affairs of the Republic of Serbia. From 2007 he has been teaching assistant at Faculty of Political Science at several courses including Public International Law, EU Law and International Humanitarian Law. He was working as personal assistant of Chief Legal Advisor in the Ministry of Foreign Affairs of the Republic of Serbia. Miloš Hrnjaz is $\mathrm{PhD}$ candidate with the approved thesis Formation and Identification of International Customary Law: the Practice of International Court of Justice. His research interests are sources of international law, prohibition of use of force in international relations and International Court of Justice.

Milan Krstić (milan.krstic@fpn.bg.ac.rs) is Teaching Assistant in International Studies at University of Belgrade Faculty of Political Sciences, and he is also a PhD Candidate in International and European Studies at the same institution. 
ก Milan Krstić graduated from London School of Economics and Political Science (MSc in History of International Relations) in 2013 and obtained BA degree in International Politics from University of Belgrade Faculty of Political Sciences in 2012. His main research interests are foreign and security policy of the Republic of Serbia, international relations theory, history and contemporary practice of the political relations in the Southeastern Europe. He is author of a number of articles in these fields. 